\title{
The overexpression of caveolin- 1 and caveolin- 2 correlates with a poor prognosis and tumor progression in esophageal squamous cell carcinoma
}

\author{
TAKUYA ANDO, HIDEYUKI ISHIGURO, MASAHIRO KIMURA, AKIRA MITSUI, YOICHIRO MORI, \\ NOBUYOSHI SUGITO, KEISUKE TOMODA, RYOTA MORI, KOSHIRO HARADA, TAKEYASU KATADA, \\ RYO OGAWA, YOSHITAKA FUJII and YOSHIYUKI KUWABARA \\ Department of Surgery II, Nagoya City University Medical School, \\ 1 Kawasumi, Mizuho-cho, Mizuho-ku, Nagoya 467-8601, Japan
}

Received March 22, 2007; Accepted May 31, 2007

\begin{abstract}
Caveolin-1 (CAV1) and caveolin-2 (CAV2) are the major structural proteins of caveolae. We investigated the relationship between the clinicopathological factors of esophageal squamous cell carcinoma (ESCC) and the expression of CAV1 and CAV2. CAV1 and CAV2 expression were analyzed by quantitative reverse transcription-polymerase chain reaction (RT-PCR) in 15 esophageal cancer cell lines (TE1-15) and a normal esophageal epithelium cell line (Het-1A). CAV1 and CAV2 expression was examined by RT-PCR and immunohistochemical analysis in 47 ESCC specimens. High levels of $C A V 1$ and $C A V 2$ mRNA were detected in TE1-15, but neither CAV1 nor CAV2 mRNA were detected in Het-1A. In the ESCC samples CAVI and CAV2 mRNA expression in the ESCC samples were significantly higher than in the corresponding normal esophageal mucosa (CAV1, $\mathrm{P}=0.0024$; CAV2, $\mathrm{P}=0.0136$ ). However, we could not find any significant relationship between $C A V 1$ or $C A V 2$ mRNA expression and clinicopathological factors. Immunostaining for CAV1 was positive in 13 of 47 patients $(27.7 \%)$, whereas CAV2 was positive in 22 of 47 patients (46.8\%). A significant correlation was observed between CAV1 and CAV2 immunostaining and T factor, lymphatic invasion, vein invasion and differentiation. The patients with positive staining for CAV1 or CAV2 had a significantly shorter survival than those with negative staining $(\mathrm{P}=0.0105$ and 0.0424 for CAV1 and CAV2, respectively). These results suggest that positive staining for CAV1 and CAV2 could be a potentially useful prognostic marker of ESCC.
\end{abstract}

Correspondence to: Dr Hideyuki Ishiguro, Department of Surgery II, Nagoya City University Medical School, 1 Kawasumi, Mizuho-cho, Mizuho-ku, Nagoya 467-8601, Japan

E-mail: h-ishi@med.nagoya-cu.ac.jp

Key words: caveolin-1, caveolin-2, esophageal squamous cell carcinoma

\section{Introduction}

Esophageal squamous cell carcinoma (ESCC) is one of the most malignant tumors in the gastrointestinal carcinoma family. Patients with ESCC generally have a poor prognosis despite intensive multimodality therapy involving surgery, radiation and chemotherapy. Recent molecular biological studies have revealed that ESCC is caused by the accumulation of multiple genetic defects in dominant oncogenes and tumor suppressors. We have also reported the expression of surviving (1), DFF45/ICAD (2), PTTG (3), Chfr (4), PPAR (5), ERCC3 (6), PABPC1 (7) and ACP6 (8) to significantly correlate with the tumor progression and prognosis in patients with ESCC.

Caveolae, which are 50-100 $\mathrm{nm}$ protein-coated invaginations of the plasma membrane, play an important role in endocytosis and signal transduction $(9,10)$. Caveolins, the major structural proteins in caveolae, include caveolin-1, -2 and -3 . Caveolin-1 (CAV1) and caveolin-2 (CAV2) are coexpressed and form a heterooligomeric complex in many cell types, with particularly high levels in adipocytes (11). CAV1 expression has been reported to increase in cancer of the prostate $(12,13)$, pancreas (14), colon (15), breast (16) and esophagus (17), thus suggesting it to play a positive role in tumor progression. Paradoxically, the CAV1 expression has been observed to decrease in lung (18), colon (19), ovary $(20)$, breast $(21,22)$ and thyroid cancer $(23)$. These data may imply that CAV1 has multiple activities in cancer depending on its interaction with other signaling molecules and the specific cell type or tissue in which it is expressed. Therefore, whether caveolins promote or suppress tumor progression remains controversial.

On the other hand, CAV2 has been reported to have a similar distribution and tissue expression as CAV1, and CAV2 is also an accessory protein that functions in conjunction with CAV1. CAV2 expression has been reported to increase in breast cancer (16), whereas it has been reported to decrease in cancer of lung $(18)$, breast $(16,21)$ and thyroid (23). However, the clinical significance of CAV2 has been less extensively studied than that of CAV1.

A microarray analysis has shown CAV1 and CAV2 to be up-regulated in ESCC cell lines (24). In this study, we 
examined CAV1 and CAV2 expression of ESCC by quantitative reverse transcription-polymerase chain reaction (RT-PCR) and immunohistochemical analysis in order to clarify the significance of CAV1 and CAV2.

\section{Materials and methods}

Cell lines and tissue samples. The esophageal cancer cell lines (TE series) were purchased from the Japanese Cancer Research Resources Bank. The SV40-immortalized esophageal cell line Het-1A was purchased from the American Type Culture Collection. TE esophageal cancer cells were plated in tissue culture dishes and then were grown in RPMI1640 medium (Sigma) containing 10\% fetal bovine serum (JRH Bioscience) at $37^{\circ} \mathrm{C}$ in a humidified atmosphere of $95 \%$ air and $5 \% \mathrm{CO}_{2}$. Het-1A cells were grown in an LHC-9 serum-free medium (Biofluids, Rockville, MD) in tissue culture dishes at $37^{\circ} \mathrm{C}$ in a humidified atmosphere of $95 \%$ air and $5 \% \mathrm{CO}_{2}$.

The samples were obtained from 47 patients with primary ESCC who had undergone a radical esophagectomy between 1997 and 2002 at the Department of Surgery II, Nagoya City University Medical School. The study design was approved by the institutional review board of Nagoya City University Medical School, and written consent was obtained from all patients. The tumors were classified according to the Japanese guidelines for clinical and pathological studies on carcinoma of the esophagus. Tissue specimens were collected from 40 males and 7 females, with a mean age of $63.5 \pm 7.5$ years (range, 45-76 years). All samples were frozen immediately in liquid nitrogen and then were stored at $-80^{\circ} \mathrm{C}$ until use. All tissue specimens for immunohistochemistry were fixed in formalin and embedded in paraffin. The characteristics of the 47 patients with ESCC are shown in Table I.

RNA extraction and RT-PCR analysis. Total-RNA was extracted from the esophageal cancer tissue and from the corresponding normal esophageal mucosa (taken from the apparently non-cancerous mucosa as far away from the tumor as possible) using the Isogen kit (Nippon Gene, Tokyo, Japan) according to the manufacturer's instructions. Total-RNA from the cell lines was similarly extracted. The concentration of the total-RNA was adjusted to $200 \mathrm{ng} / \mathrm{ml}$ using a spectrophotometer. The reverse transcription reaction was carried out using $1 \mu \mathrm{g}$ of total-RNA, $0.5 \mu \mathrm{g}$ of oligo(dT) primer, and Superscript II enzyme (Gibco BRL, Gaithersburg, MD) for $90 \mathrm{~min}$ at $42^{\circ} \mathrm{C}$ followed by $5 \mathrm{~min}$ at $95^{\circ} \mathrm{C}$ and $15 \mathrm{~min}$ at $72^{\circ} \mathrm{C}$.

TaqMan gene expression assay. Gene expression in all samples was measured by quantitative RT-PCR using an 7700 ABI PRISM Sequence Detector System (Applied Biosystems, Foster City, CA). PCR was performed in a $20-\mu 1$ reaction mixture containing $10 \mu \mathrm{l}$ of TaqMan Universal PCR Master Mix (Applied Biosystems), $80 \mathrm{nM}$ of each primer, $2 \mathrm{nM}$ of probe, and $2 \mu 1$ of cDNA sample. The thermal cycling conditions included an initial denaturation step of $95^{\circ} \mathrm{C}$ for $15 \mathrm{sec}$ and $60^{\circ} \mathrm{C}$ for $1 \mathrm{~min}$. The relative levels of mRNA expression were calculated from the relevant signals by normalization with the signal for glyceraldehyde-3-phosphate dehydrogenase
$(G A P D H)$ expression. PCR primers and fluorogenic probes for all of the target genes and endogenous controls were purchased as Assays-On-Demand (Applied Biosystems). The assays are supplied as a 20x mix of PCR primers and TaqMan minor groove binder 6-FAM dye labeled probes with a nonfluorescent quencher at the 3'-end of the probe. The assays are optimized for use on any ABI PRISM Sequence Detection System using the default machine settings. The assay numbers for $G A P D H, \mathrm{CAV} 1$ and CAV2 were as follows: Hs99999905_m1 (GAPDH); Hs00184697_m1 (CAVI); and Hs00184597_m1 (CAV2).

Immunohistochemistry. Immunohistochemical staining was performed on formalin-fixed, paraffin-embedded primary human ESCC tissues using 1:150 monoclonal anti-CAV-1 (clone 2297) or 1:50 anti-CAV-2 (clone 65) antibodies (BD Transduction Laboratories, San Jose, CA, USA). Paraffinembedded sections of tumor were deparaffinized, rehydrated, heat-treated by microwaving in $10 \mathrm{mM}$ citrate buffer for $15 \mathrm{~min}$ for antigen retrieval, and cooled to room temperature. Sections were then treated with $0.3 \% \mathrm{H}_{2} \mathrm{O}_{2}$ in methanol for $30 \mathrm{~min}$ to neutralize endogenous peroxidases, blocked with non-specific goat serum for $10 \mathrm{~min}$, and incubated with antibody H-100 overnight at room temperature in a humid chamber. Immunoreactive protein was detected with a Dako Envision $^{\mathrm{TM}}+$ System, HRP (DAB), and then the sections were counterstained with hematoxylin. The immunostaining of CAV1 and CAV2 was subjectively assessed by two independent investigators (T.A. and H.I.), and discordant results were resolved by consultation with a third investigator (Y.K.). Using light microscopy, the expression of CAV-1 and CAV-2 was scored as follows according to the proportion of positive staining throughout the entire slide: 0 , negative or $<10 \%$; 1 , $<33 \% ; 2,33-67 \%$; and 3, $>67 \%$. The status of CAV-1 and CAV-2 immunohistochemical staining was classified as negative for scores of 0 or 1 and positive for scores of 2 or 3 .

Statitical analysis. The relative mRNA expression levels ( $C A V 1 / G A P D H$ and $C A V 2 / G A P D H$ ) were calculated from the quantified data. The data are expressed as the means \pm SD. A statistical analysis was performed using the Stat-View software package (Abacus Concepts, Berkeley, CA). Wilcoxon signed-ranks test was used to evaluate the significance of the difference in the expression of $C A V 1 / G A P D H$ and $C A V 2 /$ $G A P D H$ mRNA. A correlation test was performed using Pearson's correlation coefficient. Mann-Whitney's U test, Kruskal-Wallis test and Fisher's exact test were used to analyze the association between the mRNA expression or an immunohistochemical analysis and the clinical histopathological parameters of the patients. The survival of ESCC patients after surgery was examined by the Kaplan-Meier method, and the survival time was compared using the logrank test. A multivariate analysis was performed using Cox's regression model. The $\mathrm{P}$-values were considered significant at the $\mathrm{P}<0.05$ level.

\section{Results}

Quantitative RT-PCR of $C A V-1$ and $C A V$-2. We first investigated the expression of $C A V 1$ and $C A V 2$ mRNA in 15 eso- 
Table I. Relationship between clinicopathological factors and mRNA expressions of caveolin-1 and caveolin-2.

\begin{tabular}{|c|c|c|c|c|c|}
\hline & \multirow[b]{2}{*}{ Total } & \multicolumn{2}{|c|}{ Caveolin-1 mRNA (T) } & \multicolumn{2}{|c|}{ Caveolin-2 mRNA (T) } \\
\hline & & & P-value & & P-value \\
\hline \multicolumn{6}{|l|}{ Gender } \\
\hline Male & 40 & $1.966 \pm 1.645$ & & $3.006 \pm 2.641$ & \\
\hline Female & 7 & $2.702 \pm 2.505$ & 0.4733 & $3.810 \pm 2.794$ & 0.5303 \\
\hline \multicolumn{6}{|l|}{ Age } \\
\hline$<65$ & 26 & $2.459 \pm 2.080$ & & $3.688 \pm 3.113$ & \\
\hline$\geq 65$ & 21 & $1.599 \pm 1.218$ & 0.1398 & $2.429 \pm 1.760$ & 0.0951 \\
\hline \multicolumn{6}{|l|}{$\mathrm{T}$ factor } \\
\hline $\mathrm{T} 1$ & 9 & $0.969 \pm 0.433$ & & $2.559 \pm 1.090$ & \\
\hline $\mathrm{T} 2$ & 5 & $2.787 \pm 2.655$ & & $4.716 \pm 4.851$ & \\
\hline $\mathrm{T} 3$ & 21 & $2.436 \pm 1.999$ & & $3.046 \pm 2.510$ & \\
\hline $\mathrm{T} 4$ & 12 & $1.976 \pm 1.363$ & 0.2965 & $3.027 \pm 2.651$ & 0.7511 \\
\hline $\mathrm{T} 1$ & 9 & $0.969 \pm 0.433$ & & $2.559 \pm 1.090$ & \\
\hline $\mathrm{T} 2-4$ & 38 & $2.337 \pm 1.884$ & 0.0549 & $3.260 \pm 2.893$ & 0.9784 \\
\hline \multicolumn{6}{|l|}{$\mathrm{N}$ factor } \\
\hline Negative & 13 & $1.336 \pm 0.939$ & & $2.721 \pm 1.130$ & \\
\hline Positive & 34 & $2.358 \pm 1.954$ & 0.1536 & $3.280 \pm 3.037$ & 0.5363 \\
\hline \multicolumn{6}{|l|}{ Stage } \\
\hline 0 & 4 & $0.998 \pm 0.426$ & & $2.189 \pm 0.657$ & \\
\hline I & 4 & $0.991 \pm 0.550$ & & $3.028 \pm 1.485$ & \\
\hline II & 7 & $2.389 \pm 2.154$ & & $2.832 \pm 1.171$ & \\
\hline III & 14 & $2.671 \pm 2.206$ & & $3.144 \pm 2.389$ & \\
\hline IV & 18 & $1.970 \pm 1.508$ & 0.5054 & $3.455 \pm 3.648$ & 0.8557 \\
\hline $0-\mathrm{I}$ & 8 & $0.994 \pm 0.455$ & & $2.608 \pm 1.154$ & \\
\hline II-IV & 39 & $2.297 \pm 1.876$ & 0.0894 & $3.231 \pm 2.860$ & 0.9099 \\
\hline \multicolumn{6}{|c|}{ Lymphatic invasion } \\
\hline Negative & 11 & $1.743 \pm 1.950$ & & $3.449 \pm 3.460$ & \\
\hline Positive & 27 & $2.280 \pm 1.894$ & 0.3106 & $3.133 \pm 2.432$ & 0.8595 \\
\hline Unknown & 9 & & & & \\
\hline \multicolumn{6}{|l|}{ Vein invasion } \\
\hline Negative & 16 & $1.798 \pm 1.415$ & & $3.020 \pm 2.610$ & \\
\hline Positive & 22 & $2.574 \pm 2.394$ & 0.5347 & $3.504 \pm 2.933$ & 0.2872 \\
\hline Unknown & 9 & & & & \\
\hline \multicolumn{6}{|l|}{ Differentiation } \\
\hline Well & 16 & $2.353 \pm 1.971$ & & $3.162 \pm 2.562$ & \\
\hline Moderately & 24 & $2.093 \pm 1.812$ & & $3.406 \pm 2.933$ & \\
\hline Poorly & 4 & $0.583 \pm 0.362$ & 0.0924 & $1.372 \pm 1.000$ & 0.1419 \\
\hline Unknown & 3 & & & & \\
\hline
\end{tabular}

phageal cancer cell lines (TE1-15) and a normal esophageal epithelium cell line (Het-1A) by quantitative RT-RCR. High levels of $C A V 1$ and $C A V 2$ mRNA were detected in most of the esophageal cancer cell lines, but neither $C A V 1$ nor $C A V 2$ mRNA were detected in Het-1A (Fig. 1a). There was a statistically significant correlation between $C A V 1$ and $C A V 2$ mRNA in the cell lines $(\gamma 2=0.848 ; \mathrm{P}<0.0001$; Fig. $1 \mathrm{~b})$. We next examined the $C A V 1$ and $C A V 2$ mRNA expression in 47 pairs of resected ESCC tumors and their corresponding normal esophageal mucosal tissue specimens. Both $C A V 1$ 
a

- CAVI/GAPDH MRNADCAV2/GAPDH mRNA

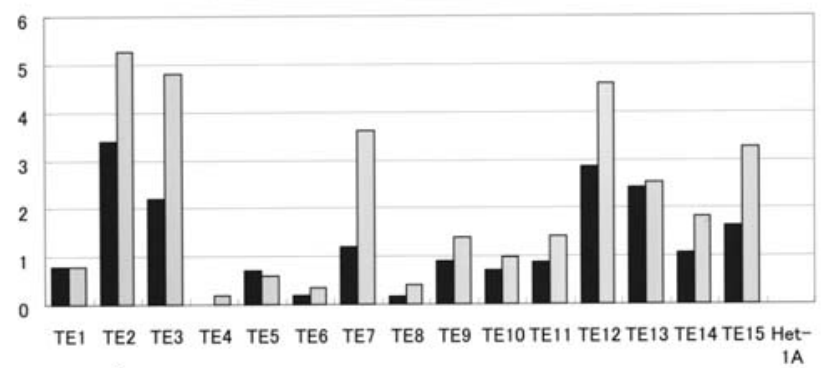

b

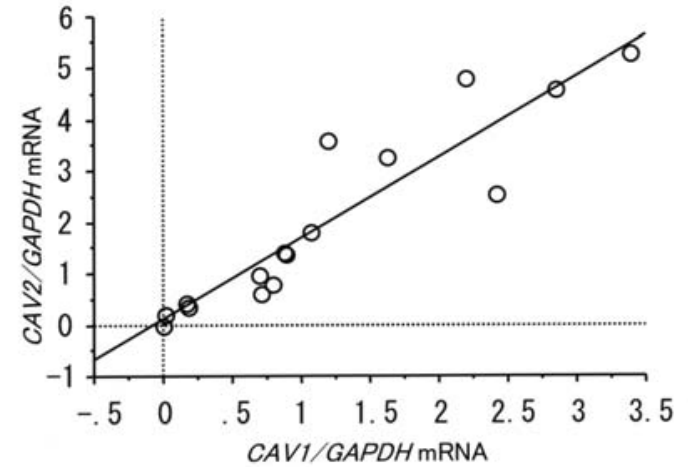

Figure 1. (a) Expression of $C A V 1$ and $C A V 2 \mathrm{mRNA}$ in cell lines. High levels of $C A V 1$ and $C A V 2$ mRNA expressions were detected in most of the ESCC cell lines, but neither CAV1 nor CAV2 mRNA were detected in the normal esophageal epithelium cell line, Het-1A. (b) The correlation between the $C A V 1$ and $C A V 2$ mRNA expression levels in the cell lines. There were significant correlations between $C A V 1$ and $C A V 2$ mRNA expression in ESCC cell lines $(\gamma 2=0.848 ; \mathrm{P}<0.0001)$.

and CAV2 mRNA were expressed in the ESCC samples at higher levels than in the corresponding normal esophageal mucosa (CAV1, P=0.0053; CAV2, P=0.0401; Fig. 2). In addition, statistically significant correlations were also observed between $C A V 1$ and $C A V 2$ mRNA in normal esophageal mucosal tissue specimens $(\gamma 2=0.629 ; \mathrm{P}<0.0001$; Fig. 3a) and cancerous tissue specimens $(\gamma 2=0.418 ; \mathrm{P}<0.0001$; Fig. 3b).

We examined the relationships between the clinicopathological factors and the expression of $C A V 1$ or $C A V 2$ mRNA in ESCC tumors. As a result, $C A V 1$ and $C A V 2$ mRNA tended to be found in more aggressive or more advanced tumors, but the difference was not significant (Table I). We also examined the relationship between the expression of $C A V 1$ or $C A V 2$ mRNA in ESCC tumors and the survival data. The $C A V 1$ and CAV2 mRNA expressions were divided into two groups (a high expression and low expression). However, we could not find any significant relationships between $C A V 1$ or $C A V 2$ mRNA expression and survival data (data not shown).

Immunostaining for $C A V-1$ and $C A V$-2. We further studied the expression of CAV1 and CAV2 protein in the ESCC tissue specimens by immunohistochemistry. Typical ESCC cells showed diffuse cytoplasmic staining, and in cases with intense staining, both the cell membrane and the cytoplasm were stained for CAV1 and CAV2 (Fig. 4b and e). Positive staining for CAV1 and CAV2 was also observed adipocytes, stromal cells in smooth muscle cells (Fig. 4e and f). In contrast, normal esophageal epithelium showed negative staining for CAV1 and CAV2 (Fig. 4a and d). Immunostaining for CAV1 and CAV2 was positive in $13(27.7 \%)$ and $22(46.8 \%)$ of 47 patients, respectively. Table II shows the relationship between the immunostaining findings for CAV1 or CAV2 and the clinicopathological factors. Immunostaining for CAV1 and CAV2 did not differ according to age, lymph node metastasis or stage. Both CAV1 and CAV2 immunostaining showed a significantly positive correlation with $\mathrm{T}$ factor, lymphatic invasion and differentiation. Both CAV1 and CAV2 proteins were overexpressed in the more aggressive ESCC tumors with local invasiveness and lymphatic invasion. Furthermore, these two proteins were more highly expressed in well-differentiated than in poorly differentiated ESCC tumors. In addition, CAV2 immunostaining was also significantly related with vein invasion and it was significantly more frequent in females than in males.

We investigated the correlation between immunostaining for CAV1 and CAV2 and survival in ESCC patients after surgery (median follow-up, 26.2 months). The patients with positive staining for CAV1 had a significantly shorter survival after surgery than the patients with negative staining $[15.7 \pm 2.5$ $(\mathrm{n}=13)$ vs. $21.1 \pm 1.5(\mathrm{n}=34)$ months, respectively; $\mathrm{P}=0.0105$ by
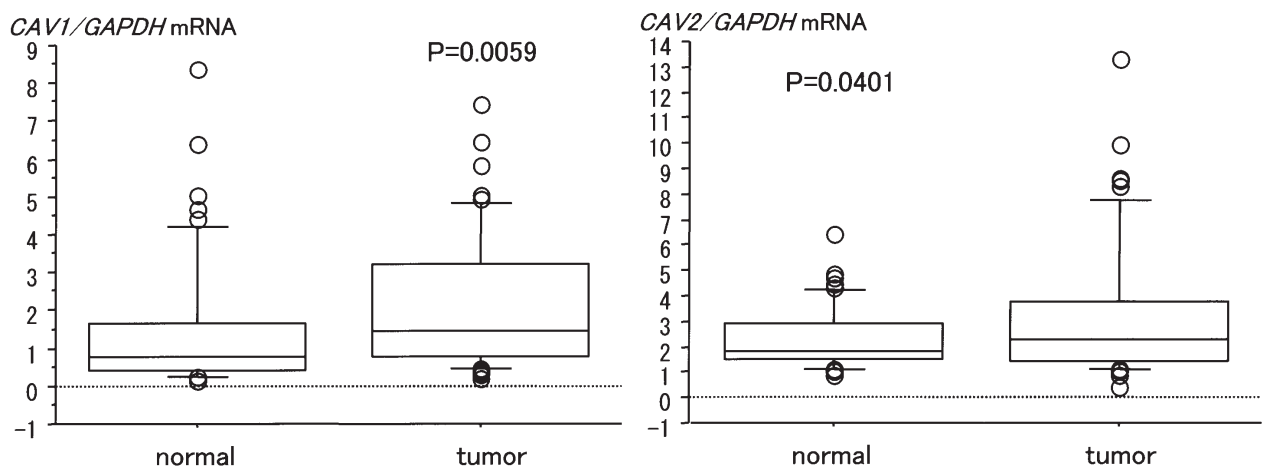

Figure 2. Comparison of the expression of CAV1 (a) and CAV2 (b) mRNAs in ESCC tissues and their corresponding normal esophageal mucosal tissues. $C A V 1$ and $C A V 2$ mRNA expression in ESCC were significantly higher than those in the corresponding normal esophageal mucosa ( $\mathrm{P}=0.0059$ and 0.0401 for CAV1 and CAV2, respectively, according to Wilcoxon signed-ranks test). 

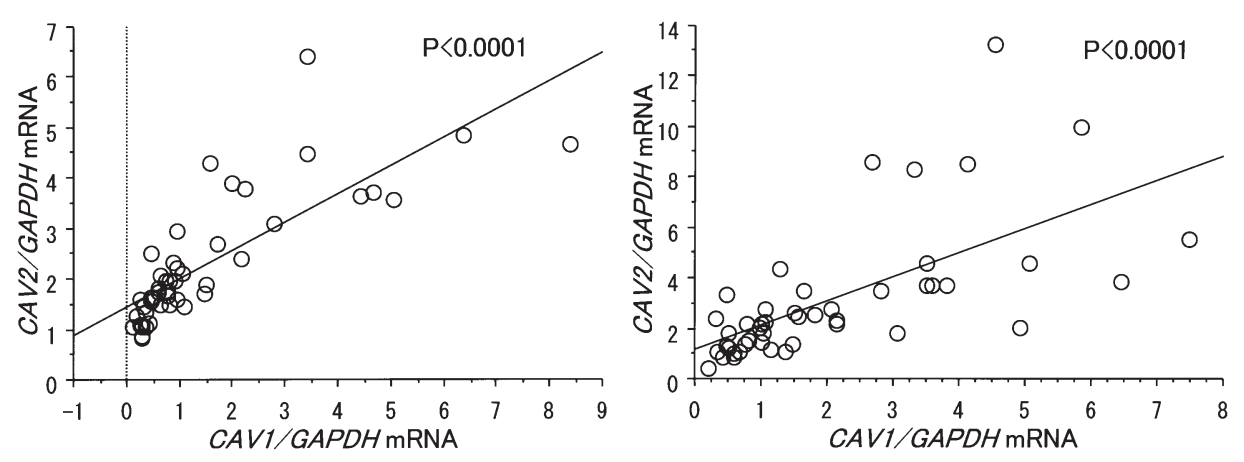

Figure 3. Correlation between the CAV1 and CAV2 mRNA expression levels in normal esophageal mucosal tissues (a) and ESCC tissues (b). Statistically significant correlations were observed between $C A V 1$ and $C A V 2$ mRNA expression in normal esophageal mucosal tissues $(\gamma 2=0.629$; $\mathrm{P}<0.0001)$ and cancerous tissues $(\gamma 2=0.418 ; \mathrm{P}<0.0001)$.
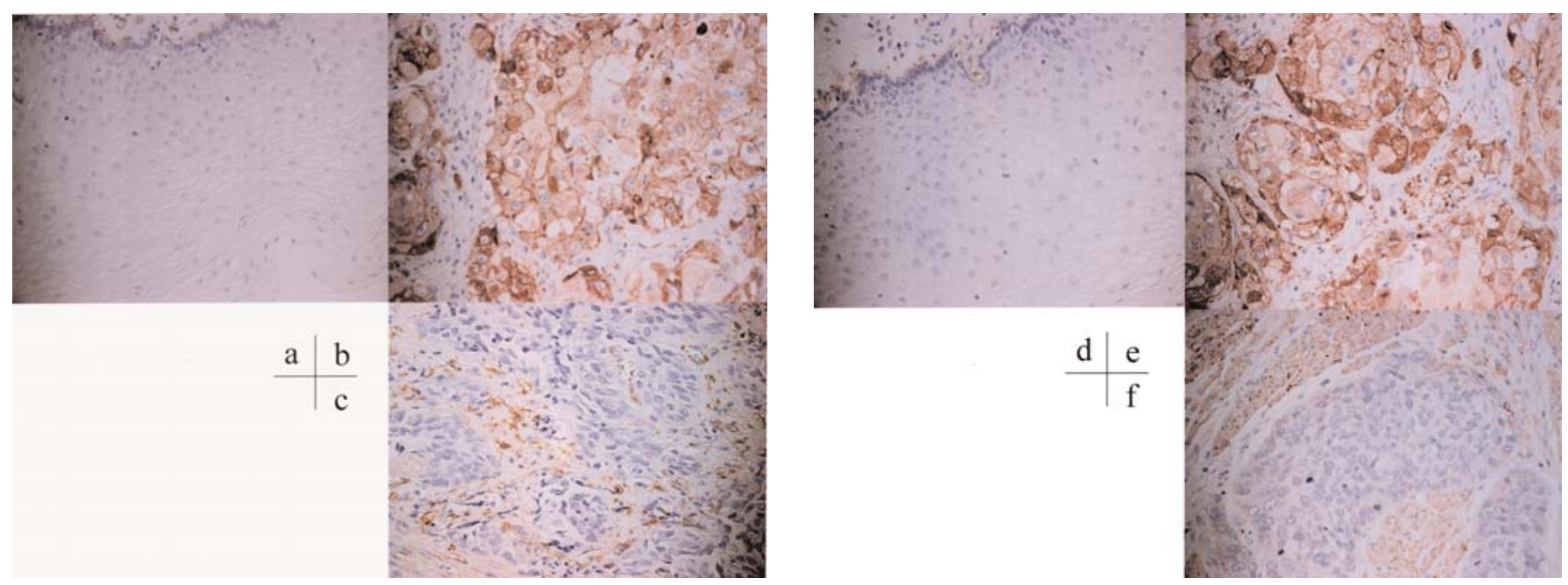

Figure 4. Representative immunostaining for CAV1 and CAV2 (x400). (a) Negative staining of CAV1 in normal esophageal mucosa. (b) Positive staining in CAV1 in tumor cells. (c) Negative staining for CAV1 in tumor cells but strong staining of the stroma. (d) Negative staining for CAV2 in normal esophageal mucosa. (e) Positive staining for CAV2 in tumor cells. (f) Negative staining for CAV2 in tumor cells but strong staining for smooth muscle cells.

log-rank test; Fig. 5a]. In addition, the patients with positive staining for CAV2 had a significantly shorter survival after surgery than the patients with negative staining $[17.3 \pm 2.1$ months $(n=22)$ vs. $31.3 \pm 3.3$ months $(n=25) ; P=0.0424$ by log-rank test; Fig. 5b].

A univariate analysis showed that, among the clinicopathological factors, the extent of primary tumor (risk ratio, 6.463; $\mathrm{P}=0.0123$ ), lymph node metastasis (risk ratio, 5.532; $\mathrm{P}=0.0214$ ), vein invasion (risk ratio, 4.323; $\mathrm{P}=0.0241$ ), immunostaining for CAV1 (risk ratio, 2.842; $\mathrm{P}=0.0155$ ) were all statistically significant prognostic factors, whereas immunostaining for CAV2 was not found to be a prognostic factor in univariate analysis (Table III). The multivariate analysis revealed that positive staining for CAV1 was an independent prognostic factor (risk ratio, 3.858; $\mathrm{P}=0.0164$ ), as well as lymph node metastasis (risk ratio, 10.238; $\mathrm{P}=0.0303$ ) (Table IV).

\section{Discussion}

Caveolins are the major structural proteins of caveolae and have been reported to interact with various intracellular signaling molecules including epidermal growth factor receptor (25), HER2 (21), c-myc (26), transforming growth factor- $ß /$ SMAD (27) and the Wnt pathway (28). The expression and function of CAV1 has been examined in several cancers such as prostate $(12,13)$, pancreas $(14)$, colon $(15,19)$, lung $(18)$, ovary $(20)$, breast $(16,21,22)$ and thyroid cancer $(23)$, whereas just a few investigations on CAV2 have so far been reported in breast $(16,21)$, lung (18) and thyroid cancer (23). To the best of our knowledge, only one report has been released regarding the relationship between the immunostaining for CAV1 and the prognosis of ESCC (17). However, CAV2 expression has not yet been examined in ESCC. In this study we evaluated the expression of both CAV1 and CAV2 in ESCC, not only by quantitative RT-PCR but also by immunostaining.

We thus demonstrated that the expressions of both $C A V 1$ and $C A V 2$ mRNA were significantly higher in the tumor tissues than in the corresponding normal tissues, in addition to the ESCC cell lines. However, they did not correlate with the clinicopathological factors and thus could not be prognosis factors. The expression of both CAV1 and CAV2 protein significantly correlated with several clinicopatho- 
Table II. Relationship between clinicopathological factors and immunostaining for CAV1and CAV2.

\begin{tabular}{|c|c|c|c|c|c|c|c|}
\hline & \multirow[b]{2}{*}{ Total } & \multicolumn{3}{|c|}{ CAV1 } & \multicolumn{3}{|c|}{ CAV2 } \\
\hline & & $\begin{array}{c}\text { Negative } \\
34\end{array}$ & $\begin{array}{c}\text { Positive } \\
13\end{array}$ & P-value & $\begin{array}{c}\text { Negative } \\
25\end{array}$ & $\begin{array}{c}\text { Positive } \\
22\end{array}$ & P-value \\
\hline \multicolumn{8}{|l|}{ Gender } \\
\hline Male & 40 & 31 & 9 & & 24 & 16 & \\
\hline Female & 7 & 3 & 4 & 0.0805 & 1 & 6 & 0.0400 \\
\hline \multicolumn{8}{|l|}{ Age } \\
\hline$<65$ & 26 & 17 & 9 & & 14 & 12 & \\
\hline$\geq 65$ & 21 & 17 & 4 & 0.3300 & 11 & 10 & $>0.9999$ \\
\hline \multicolumn{8}{|l|}{$\mathrm{T}$ factor } \\
\hline $\mathrm{T} 1$ & 9 & 9 & 0 & & 8 & 1 & \\
\hline T2 & 5 & 4 & 1 & & 3 & 2 & \\
\hline T3 & 21 & 13 & 8 & & 7 & 14 & \\
\hline $\mathrm{T} 4$ & 12 & 8 & 4 & 0.1775 & 7 & 5 & 0.0430 \\
\hline T1 & 9 & 9 & 0 & & 8 & 1 & \\
\hline $\mathrm{T} 2-4$ & 38 & 25 & 13 & 0.0468 & 17 & 21 & 0.0252 \\
\hline \multicolumn{8}{|l|}{$\mathrm{N}$ factor } \\
\hline Negative & 13 & 11 & 2 & & 9 & 4 & \\
\hline Positive & 34 & 23 & 11 & 0.3007 & 16 & 18 & 0.2071 \\
\hline \multicolumn{8}{|l|}{ Stage } \\
\hline 0 & 4 & 4 & 0 & & 4 & 0 & \\
\hline I & 4 & 4 & 0 & & 3 & 1 & \\
\hline II & 7 & 4 & 3 & & 2 & 5 & \\
\hline III & 14 & 10 & 4 & & 7 & 7 & \\
\hline IV & 18 & 12 & 6 & 0.3845 & 9 & 9 & 0.1904 \\
\hline $0-\mathrm{I}$ & 8 & 8 & 0 & & 7 & 1 & \\
\hline II-IV & 42 & 26 & 13 & 0.0855 & 18 & 21 & 0.0516 \\
\hline \multicolumn{8}{|c|}{ Lymphatic invasion } \\
\hline Negative & 11 & 11 & 0 & & 11 & 0 & \\
\hline Positive & 27 & 18 & 9 & 0.0378 & 10 & 17 & 0.003 \\
\hline Unknown & 10 & - & - & & - & - & \\
\hline \multicolumn{8}{|l|}{ Vein invasion } \\
\hline Negative & 16 & 15 & 1 & & 14 & 2 & \\
\hline Positive & 22 & 14 & 8 & 0.0525 & 7 & 15 & 0.0009 \\
\hline Unknown & 10 & - & - & & - & - & \\
\hline \multicolumn{8}{|l|}{ Differentiation } \\
\hline Well & 16 & 8 & 8 & & 3 & 13 & \\
\hline Moderately & 24 & 20 & 4 & & 16 & 8 & \\
\hline Poorly & 4 & 4 & 0 & 0.0298 & 4 & 0 & 0.0016 \\
\hline Unknown & 3 & - & - & & - & - & \\
\hline
\end{tabular}

logical factors including $\mathrm{T}$ factor, lymphatic invasion, and differentiation. Positive staining for CAV1 or CAV2 had a significant correlation with a poor survival after surgery, and both of CAV1 and CAV2 protein expression could thus be prognosis factors according to the log-rank test. These results implied that both CAV1 and CAV2 might therefore play a role in the development and differentiation of ESCC. Our results were similar to those of previous reports which 
a
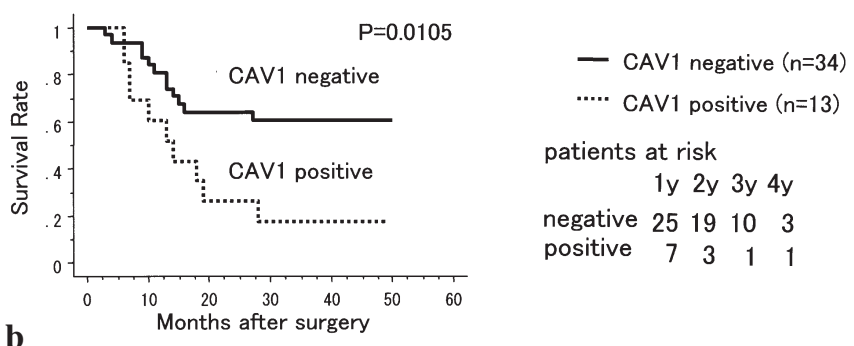

patients at risk

1 y 2 y $3 y 4 y$

negative $\begin{array}{llll}25 & 19 & 10 & 3\end{array}$

positive $\begin{array}{llll}7 & 3 & 1 & 1\end{array}$

b
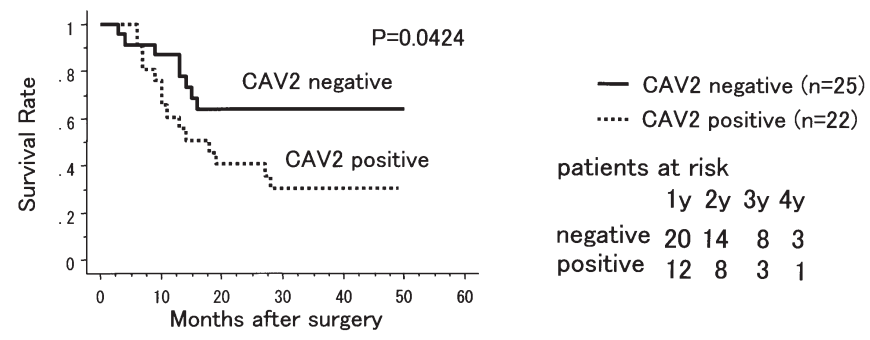

patients at risk

1 y 2 y $3 y 4 y$

negative $\begin{array}{llll}20 & 14 & 8 & 3\end{array}$

positive $\begin{array}{llll}12 & 8 & 3\end{array}$

Figure 5. Survival rate of patients with ESCC according to CAV1 and CAV2 immunostaining. (a) Patients with positive staining for CAV1 had a significantly shorter survival after surgery than patients with negative staining for CAV1 $(\mathrm{P}=0.0105)$. (b) Patients with positive staining for CAV2 had a significantly shorter survival after surgery than patients with negative staining for CAV2 $(\mathrm{P}=0.0424)$.

described the CAV1 expression to increase in cancer of prostate (12,13), pancreas (14), colon (15), breast cancer (16) and esophagus (17). Overexpression of CAV2 has also been reported in breast cancer (16). Our findings suggest that not only CAV1 but also CAV2 may thus play an important role in tumor progression. However, the precise mechanism of tumor progression mediated by caveolin remains to be eludicated. Caveolae was proposed to regulate the cellular signaling pathways, because many receptors and signal transduction molecules are concentrated within the caveolae. Especially CAV1 is considered to play a role in both cell survival and tumor progression, by activating the PI3-K/Akt pathway (29) and interacting with GTP binding proteins (30) and C-Src (31). The functions of caveolin might thus be regulated by these intracellular signaling pathways.

In our study, positive staining for CAV1 and CAV2 in tumor tissue was higher in females than in males. In particular, positive staining in females was significantly high in CAV2. This suggests that the expression of caveolins, including CAV1 and CAV2, may be related to gender, because E2 (17B-estradiol) has been reported to stimulate CAV1 and CAV2 protein expression in smooth muscle cells (32).

In this study, we also demonstrated an increased expression of CAV1 and CAV2 both at mRNA level and at the protein level, and moreover a significant correlation between the CAV1 and CAV2 expression in both the cell lines and resected ESCC samples. Previously, CAV2 was not implicated to play an important role in cancer, while CAV2 was thought to be an accessory protein of CAV1. However, considering that CAV1 and CAV2 are the main structural components of caveolae and they form a heterooligomeric complex (11), our findings suggest that CAV2 may therefore also play an important role in intracellular signaling as well as CAV1. In
Table III. Univariate analysis.

\begin{tabular}{|c|c|c|c|}
\hline Parameter & Risk ratio & $95 \% \mathrm{CI}^{\mathrm{a}}$ & P-value \\
\hline \multicolumn{4}{|l|}{ Age at surgery } \\
\hline$<65$ & 1 & & \\
\hline$\geq 65$ & 1.485 & $0.614-3.440$ & 0.3557 \\
\hline \multicolumn{4}{|l|}{ Gender } \\
\hline Female & 1 & & \\
\hline Male & 1.224 & $0.362-4.138$ & 0.7449 \\
\hline \multicolumn{4}{|l|}{ Histlogical grade } \\
\hline Moderately/poorly & 1 & & \\
\hline Well & 1.775 & $0.720-4.373$ & 0.2124 \\
\hline \multicolumn{4}{|l|}{ Primary tumor } \\
\hline $\mathrm{T} 1-2$ & 1 & & \\
\hline T3-4 & 6.463 & $1.499-27.873$ & 0.0123 \\
\hline \multicolumn{4}{|l|}{$\begin{array}{l}\text { Lymph node } \\
\text { metastasis }\end{array}$} \\
\hline Negative & 1 & & \\
\hline Positive & 5.532 & $1.288-23.766$ & 0.0214 \\
\hline \multicolumn{4}{|l|}{ Lymphatic invasion } \\
\hline Negative & 1 & & \\
\hline Positive & 7.364 & $0.965-56.220$ & 0.0542 \\
\hline \multicolumn{4}{|l|}{ Vein invasion } \\
\hline Negative & 1 & & \\
\hline Positive & 4.323 & $1.211-15.436$ & 0.0241 \\
\hline \multicolumn{4}{|l|}{$\begin{array}{l}\text { Immunostaining } \\
\text { for CAV1 }\end{array}$} \\
\hline Negative & 1 & & \\
\hline Positive & 2.842 & $1.220-6.621$ & 0.0155 \\
\hline \multicolumn{4}{|l|}{$\begin{array}{l}\text { Immunostaining } \\
\text { for CAV2 }\end{array}$} \\
\hline Negative & 1 & & \\
\hline Positive & 2.377 & $0.994-5.684$ & 0.0515 \\
\hline
\end{tabular}

${ }^{\mathrm{a}} \mathrm{CI}$, confidence interval.

resected ESCC samples, the expression of CAV1 and CAV2 protein was significantly related with clinicopathological factors. Therefore, the overexpression of both CAV1 and CAV2 may contribute to tumor progression in ESCC.

This is the first study to demonstrate the clinical significance of both CAV1 and CAV2 expression in ESCC. In particular the expression of CAV2 has not been previously examined in ESCC. Our results showed that immunostaining for CAV1 and CAV2 may be more effective than mRNA expression for determining the malignant potential of ESCC. We showed that positive immunostaining for CAV1 and CAV2 could be prognostic factors in ESCC. Furthermore, the multivariate analysis showed positive immunostaining for 
Table IV. Multivariate analysis including CAV1.

\begin{tabular}{lccc}
\hline Parameter & Risk ratio & $95 \%$ CI $^{\mathrm{a}}$ & P-value \\
\hline $\begin{array}{l}\text { Primary tumor } \\
\text { T1-2 }\end{array}$ & 1 & & \\
T3-4 & 3.723 & $0.767-18.071$ & 0.1029 \\
Lymph node & & & \\
metastasis & & & \\
Negative & 1 & & \\
Positive & 10.238 & $1.247-84.033$ & 0.0303 \\
Vein invasion & & & \\
Negative & 1 & & 0.1084 \\
Positive & 2.914 & $0.790-10.752$ & \\
Immunostaning & & & \\
for CAV1 & & & 0.0164 \\
Negative & 1 & & \\
Positive & 3.858 & $1.281-11.614$ &
\end{tabular}

${ }^{\mathrm{a}} \mathrm{CI}$, confidence interval.

CAV1 to be an independent prognosis factor, although that for CAV2 was not. Since positive staining of CAV1 might be a more significant prognostic marker than CAV2, the assessment of positive staining of CAV1 and CAV2 is a candidate prognostic marker for patients with ESCC. Caveolins including CAV1 and CAV2 might therefore be new therapeutic targets in ESCC.

\section{Acknowlegements}

The authors thank Ms. Shinobu Makino for her excellent technical assistance.

\section{References}

1. Kato J, Kuwabara Y, Mitani M, Shinoda N, Sato A, Toyama T, Mitsui A, Nishiwaki T, Moriyama S, Kudo J and Fujii Y: Expression of survivin in esophageal cancer: correlation with the prognosis and response to chemotherapy. Int J Cancer 95: 92-95, 2001.

2. Konishi S, Ishiguro H, Shibata $Y$, Kudo J, Terashita $Y$, Sugiura H, Koyama H, Kimura M, Sato A, Shinoda N, Kuwabara Y and Fujii Y: Decreased expression of DFF45/ICAD is correlated with a poor prognosis in patients with esophageal carcinoma. Cancer 95: 2473-2478, 2002.

3. Shibata Y, Haruki N, Kuwabara Y, Nishiwaki T, Kato J, Shinoda N, Sato A, Kimura M, Koyama H, Toyama T, Ishiguro H, Kudo J, Terashita Y, Konishi S and Fujii Y: Expression of PTTG (pituitary tumor transforming gene) in esophageal cancer. Jpn J Clin Oncol 32: 233-237, 2002.

4. Shibata Y, Haruki N, Kuwabara Y, Ishiguro H, Shinoda N, Sato A, Kimura M, Koyama H, Toyama T, Nishiwaki T, Kudo J, Terashita Y, Konishi S, Sugiura H and Fujii Y: Chfr expression is downregulated by $\mathrm{CpG}$ island hypermethylation in esophageal cancer. Carcinogenesis 23: 1695-1699, 2002.

5. Terashita Y, Sasaki H, Haruki N, Nishiwaki T, Ishiguro H, Shibata Y, Kudo J, Konishi S, Kato J, Koyama H, Kimura M, Sato A, Shinoda N, Kuwabara Y and Fujii Y: Decreased peroxisome proliferator-activated receptor gamma gene expression is correlated with poor prognosis in patients with esophageal cancer. Jpn J Clin Oncol 32: 238-243, 2002.
6. Terashita Y, Ishiguro H, Haruki N, Sugiura H, Tanaka T, Kimura M, Shinoda N, Kuwabara Y and Fujii Y: Excision repair cross complementing 3 expression is involved in patient prognosis and tumor progression in esophageal cancer. Oncol Rep 12: 827-831, 2004.

7. Takashima $\mathrm{N}$, Ishiguro $\mathrm{H}$, Kuwabara $\mathrm{Y}$, Kimura M, Haruki N, Ando T, Kurehara H, Sugito N, Mori R and Fujii Y: Expression and prognostic roles of PABPC1 in esophageal cancer: correlation with tumor progression and postoperative survival. Oncol Rep 15: 667-671, 2006.

8. Ando T, Ishiguro H, Kuwabara Y, Kimura M, Mitsui A, Kurehara H, Sugito N, Tomoda K, Mori R, Takashima N, Ogawa R and Fujii Y: Expression of ACP6 is an independent prognostic factor for poor survival in patients with esophageal squamous cell carcinoma. Oncol Rep 15: 1551-1555, 2006.

9. Marx J: Caveolae: a once-elusive structure gets some respect. Science 294: 1862-1865, 2001.

10. Galbiati F, Razani B and Lisanti MP: Emerging themes in lipid rafts and caveolae. Cell 106: 403-411, 2001.

11. Scherer PE, Lewis RY, Volonte D, Engelman JA, Galbiati F, Couet J, Kohtz DS, van Donselaar E, Peters P and Lisanti MP: Cell-type and tissue-specific expression of caveolin-2. Caveolins 1 and 2 co-localize and form a stable heterooligomeric complex in vivo. J Biol Chem 272: 29337-29346, 1997.

12. Smart EJ, Graf GA, McNiven MA, Sessa WC, Engelman JA, Scherer PE, Okamoto T and Lisanti MP: Caveolins, liquidordered domains, and signal transduction. Mol Cell Biol 19: 7289-7304, 1999.

13. Williams TM, Hassan GS, Li J, Cohen AW, Medina F, Frank PG, Pestell RG, Di Vizio D, Loda M and Lisanti MP: Caveolin-1 promotes tumor progression in an autochthonous mouse model of prostate cancer: genetic ablation of Cav-1 delays advanced prostate tumor development in tramp mice. J Biol Chem 280: 25134-25145, 2005.

14. Suzuoki M, Miyamoto M, Kato K, Hiraoka K, Oshikiri T, Nakakubo Y, Fukunaga A, Shichinohe T, Shinohara T, Itoh T, Kondo $\mathrm{S}$ and Katoh H: Impact of caveolin-1 expression on prognosis of pancreatic ductal adenocarcinoma. Br J Cancer 87: 1140-1144, 2002.

15. Fine SW, Lisanti MP, Galbiati F and Li M: Elevated expression of caveolin-1 in adenocarcinoma of the colon. Am J Clin Pathol 115: 719-724, 2001.

16. Van den Eynden GG, van Laere SJ, van der Auwera I, Merajver SD, van Marck EA, van Dam P, Vermeulen PB, Dirix LY and van Golen KL: Overexpression of caveolin-1 and -2 in cell lines and in human samples of inflammatory breast cancer. Breast Cancer Res Treat 95: 219-228, 2006.

17. Kato K, Hida Y, Miyamoto M, Hashida H, Shinohara T, Itoh T, Okushiba S, Kondo S and Katoh $\mathrm{H}$ : Overexpression of caveolin-1 in esophageal squamous cell carcinoma correlates with lymph node metastasis and pathologic stage. Cancer 94: 929-933, 2002.

18. Wikman H, Seppanen JK, Sarhadi VK, Kettunen E, Salmenkivi K, Kuosma E, Vainio-Siukola K, Nagy B, Karjalainen A, Sioris T, Salo J, Hollmen J, Knuutila S and Anttila S: Caveolins as tumour markers in lung cancer detected by combined use of cDNA and tissue microarrays. J Pathol 203: 584-593, 2004.

19. Bender FC, Reymond MA, Bron C and Quest AF: Caveolin-1 levels are down-regulated in human colon tumors, and ectopic expression of caveolin-1 in colon carcinoma cell lines reduces cell tumorigenicity. Cancer Res 60: 5870-5878, 2000.

20. Davidson B, Nesland JM, Goldberg I, Kopolovic J, Gotlieb WH, Bryne M, Ben-Baruch G, Berner A and Reich R: Caveolin-1 expression in advanced-stage ovarian carcinoma - a clinicopathologic study. Gynecol Oncol 81: 166-171, 2001.

21. Sagara Y, Mimori K, Yoshinaga K, Tanaka F, Nishida K, Ohno S, Inoue $\mathrm{H}$ and Mori M: Clinical significance of Caveolin-1, Caveolin-2 and HER2/neu mRNA expression in human breast cancer. Br J Cancer 91: 959-965, 2004.

22. Sloan EK, Stanley KL and Anderson RL: Caveolin-1 inhibits breast cancer growth and metastasis. Oncogene 23: 7893-7897, 2004.

23. Aldred MA, Ginn-Pease ME, Morrison CD, Popkie AP, Gimm O, Hoang-Vu C, Krause U, Dralle H, Jhiang SM, Plass C and Eng C: Caveolin-1 and caveolin-2,together with three bone morphogenetic protein-related genes, may encode novel tumor suppressors down-regulated in sporadic follicular thyroid carcinogenesis. Cancer Res 63: 2864-2871, 2003. 
24. Hu YC, Lam KY, Law S, Wong J and Srivastava G: Profiling of differentially expressed cancer-related genes in esophageal squamous cell carcinoma (ESCC) using human cancer cDNA arrays: overexpression of oncogene MET correlates with tumor differentiation in ESCC. Clin Cancer Res 7: 3519-3525, 2001.

25. Couet J, Sargiacomo M and Lisanti MP: Interaction of a receptor tyrosine kinase, EGF-R, with caveolins. Caveolin binding negatively regulates tyrosine and serine/threonine kinase activities. J Biol Chem 272: 30429-30438, 1997.

26. Timme TL, Goltsov A, Tahir S, Li L, Wang J, Ren C, Johnston RN and Thompson TC: Caveolin-1 is regulated by cmyc and suppresses c-myc-induced apoptosis. Oncogene 19: 3256-3265, 2000.

27. Razani B, Zhang XL, Bitzer M, von Gersdorff G, Bottinger EP and Lisanti MP: Caveolin-1 regulates transforming growth factor (TGF)-beta/SMAD signaling through an interaction with the TGF-beta type I receptor. J Biol Chem 276: 6727-6738, 2001.

28. Galbiati F, Volonte D, Brown AM, Weinstein DE, Ben-Ze'ev A, Pestell RG and Lisanti MP: Caveolin-1 expression inhibits Wnt/beta-catenin/Lef-1 signaling by recruiting beta-catenin to caveolae membrane domains. J Biol Chem 275: 23368-23377, 2000 .
29. Li L, Ren CH, Tahir SA, Ren C and Thompson TC: Caveolin-1 maintains activated Akt in prostate cancer cells through scaffolding domain binding site interactions with and inhibition of serine/threonine protein phosphatases PP1 and PP2A. Mol Cell Biol 23: 9389-9404, 2003.

30. Gingras D, Gauthier F, Lamy S, Desrosiers RR and Beliveau R: Localization of RhoA GTPase to endothelial caveolae-enriched membrane domains. Biochem Biophys Res Commun 247: 888-893, 1998.

31. Lee H, Volonte D, Galbiati F, Iyengar P, Lublin DM, Bregman DB, Wilson MT, Campos-Gonzalez R, Bouzahzah B, Pestell RG, Scherer PE and Lisanti MP: Constitutive and growth factor-regulated phosphorylation of caveolin-1 occurs at the same site (Tyr-14) in vivo: identification of a c-Src/Cav-1/Grb7 signaling cassette. Mol Endocrinol 14: 1750-1775, 2000.

32. Razandi M, Oh P, Pedram A, Schnitzer J and Levin ER: ERs associate with and regulate the production of caveolin: implications for signaling and cellular actions. Mol Endocrinol 16: $100-115,2002$. 